\title{
Számítógépes tomográfia és hasürinyomás-mérés alkalmazása az óriás medián hegsérvek kezelésében
}

\author{
Fülöp Zsolt Zoltán dr. ${ }^{1,2}$ - Ifj. Bara Tivadar dr. ${ }^{1}$ \\ Simu Patricia dr. ${ }^{3}$. Szilveszter Mónika dr. ${ }^{4}$. Drágus Emőke dr. ${ }^{5}$ \\ Fülöp Réka Linda ${ }^{6}$ - Jung János dr. ${ }^{2}$ - Bara Tivadar dr. ${ }^{1}$ \\ ${ }^{1}$ Marosvásárhelyi Orvosi, Gyógyszerészeti, Tudomány- és Technológiai Egyetem, \\ II. Sebészeti Tanszék, Marosvásárhely \\ ${ }^{2}$ Marosvásárhelyi Orvosi, Gyógyszerészeti, Tudomány- és Technológiai Egyetem, \\ Patológiai Tanszék, Marosvásárhely \\ ${ }^{3}$ Marosvásárhelyi Orvosi, Gyógyszerészeti, Tudomány- és Technológiai Egyetem, \\ Radiológiai Tanszék, Marosvásárhely \\ ${ }^{4}$ Marosvásárhelyi Sürgősségi Megyei Klinikai Kórház, Plasztikai Sebészeti Klinika, Marosvásárhely \\ ${ }^{5}$ Marosvásárhelyi Megyei Klinikai Kórház, Urológiai Klinika, Marosvásárhely \\ ${ }^{6}$ Marosvásárhelyi Orvosi, Gyógyszerészeti, Tudomány- és Technológiai Egyetem, Marosvásárhely
}

\begin{abstract}
Bevezetés: Az óriás hasfali defektusok kezelése kihívást jelent a sebészek számára. CT-vizsgálattal meghatározható a sérvzsák és a hasüreg térfogata közötti arány, megállapítva a téraránytalanság mértékét, amely a műtét utáni hasüri nyomás mértékének kifejezője lehet.

Célkitüzés: A posztoperatív óriás hasfali defektusok kivizsgálásában alkalmazott CT-vizsgálat jelentőségének alátámasztása, a rekonstrukciós módszer hatékonyságának elemzése a hasúrinyomás-méréssel.

Módszer: Prospektív kutatást végzünk klinikánkon, vizsgálva az óriás hegsérvvel kezelt betegeinket, akiknél mútét előtt hasi CT-vizsgálat készül. A hasfal rekonstrukciója feszülésmentesen, retromuscularisan elhelyezett Prolene hálóval és sérvzsákból készített peritoneumlebenyekkel történik. Műtét alatt és mútét után hasúri nyomást mérünk, posztoperatívan 2, 4, 6 hónap után telefonon keresztül követjük betegeinket.

Eredmények: Elért eredményeinket három eset kapcsán mutatjuk be. 1. eset: A 48 éves nóbetegnél óriás kiújult hegsérv, több társbetegség állt fenn. Testtömegindexe 43,6, a hasfali defektus átméröje $155 \mathrm{~mm}$, a hegsérv térfogata 1536,63 $\mathrm{cm}^{3}$ volt. A mútét utáni 7. napon hazabocsátottuk. 2. eset: Az 51 éves férfi betegnél multilocularis óriás hegsérv keletkezett, testtömegindexe 26,85 volt. A két hasfali defektus átmérője $123 \mathrm{~mm}$ és $105 \mathrm{~mm}$, térfogatuk együttes értéke $406,41 \mathrm{~cm}^{3}$ volt. A mútét utáni 5. napon a beteget elbocsátottuk. 3. eset: A 67 éves férfi beteg testtömegindexe 23,7 , a hasfali defektus mérete $100 \mathrm{~mm}$, térfogata $258,10 \mathrm{~cm}^{3}$ volt. A beteget a mútét utáni 4 . napon elbocsátottuk.

Következtetés: A preoperatív CT-vizsgálat adatai fontosak az alkalmazott mútéti technika megválasztásában. A sérvzsák és a háló együttes alkalmazása az óriás hegsérvek rekonstrukciójában olcsó és feszülésmentes mútéti technikát biztosít a fokozott rizikóval rendelkező betegek esetében. A technika rövid távú hatékonyságának elemzésére a húgyhólyagon keresztül mért hasúri nyomás a választandó módszer.
\end{abstract}

Orv Hetil. 2020; 161(9): 347-353.

Kulcsszavak: óriás hegsérv, hasűrinyomás-mérés, feszülésmentes rekonstrukció

\section{Application of computed tomography and abdominal pressure measurement in the treatment of giant incisional hernias}

Introduction: Giant abdominal wall defects represent a major challenge for surgeons. CT scan can determine the ratio between the volume of the hernia sac and the abdominal cavity, determining the extent of the disproportion, which is related to the postoperative abdominal pressure value.

Aim: Confirmation of the significance of CT examination in postoperative giant abdominal wall defects, effectiveness analysis of the reconstruction method by abdominal pressure measurement. 
Method: A prospective study is conducted on patients with giant incisional hernias, with preoperatively performed abdominal CT scan. Tension-free abdominal wall reconstruction is realized with retromuscular Prolene mesh and hernial sac. Abdominal pressure is measured during and after surgery. Patients' follow-up is performed through phone after 2-4-6 months.

Results: We present our results through three cases. First case: 48 -year-old woman presented a giant recurrent incisional hernia and multiple comorbidities. Maximum defect diameter was: $155 \mathrm{~mm}$, hernia volume: $1536.63 \mathrm{~cm}^{3}$, $\mathrm{BMI}=43.6$. The patient was discharged after seven days. Second case: 51 -year-old male patient presented with multilocular giant incisional hernia, $\mathrm{BMI}=26,85$. Maximum diameter of the two wall defects were $123 \mathrm{~mm}$ and 105 $\mathrm{mm}$, their total volume: $406.4 \mathrm{~cm}^{3}$. The patient was discharged after five days. Third case: A 67 -year-old male patient presented with giant incisional hernia. The abdominal defect size was 100/100 mm (LL/CC), volume: 258.10 $\mathrm{cm}^{3}, \mathrm{BMI}=23.7$. The patient was discharged after four days.

Conclusion: The proper surgical technique can be established based on the preoperative CT scan. Abdominal wall reconstruction with retromuscular Prolene mesh and hernial sac provides a cheap, reliable, tension-free technique. The technique's short-term efficacy can be determined by abdominal pressure measuring through the bladder.

Keywords: giant incisional hernia, abdominal pressure, tension-free technique

Fülöp ZsZ, Bara T Jr, Simu P, Szilveszter M, Drágus E, Fülöp RL, Jung J, Bara T. [Application of computed tomography and abominal pressure measurement in the treatment of giant incisional hernias]. Orv Hetil. 2020; 161(9): $347-353$

(Beérkezett: 2019. október 18.; elfogadva: 2019. november 17.)

\section{Rövidítések}

$\mathrm{ACV}=($ abdominal cavity volume $)$ visszamaradt hasüregi térfogat; $\mathrm{AP}=$ anteroposterior; $\mathrm{BMI}=($ body mass index $)$ testtömegindex; $\mathrm{CC}=$ craniocaudalis; $\mathrm{CT}=$ (computed tomography) számítógépes tomográfia; HSV = (hernia sac volume) a hegsérv térfogata; $\mathrm{LL}=$ laterolateralis; POSSUM-skála $=($ Physiological and Operative Severity Score for the enUmeration of Mortality and morbidity) élettani és mútéti súlyossági skála a morbiditás és mortalitás számszerúsítésére; TPV = (total peritoneal volume) teljes hasüregi térfogat

A laparotomiák leggyakoribb, mútét utáni szövődményét a hasfali defektusok képezik [1]. A változatos beavatkozási eljárások, valamint a mútéti technikák fejlődése ellenére a hegsérvek kialakulása és kiújulása még mindig magas arányokat ér el [2]. A leggyakrabban a középvonalban, a köldök alatti területen fordulnak eló [1]. Számos hajlamosító tényező játszik szerepet a hegsérvek megjelenésében, recidívájában, így obesitas, $\mathrm{cu}^{-}$ korbetegség, malignus betegségek, hasû́rinyomás-fokozódást okozó elváltozások $[1,3]$. A hasfali defektusok prognózisát rontja, hogy a beteg későn jelentkezik sebészi kezelésre, mert ezalatt a sérvzsák óriás méreteket ölthet [2]. Óriás hegsérveknek nevezzük azon hasfali defektusokat, amelyek átméröje meghaladja a $10 \mathrm{~cm}-\mathrm{t}$, illetve az Európai Sérv Társaság (European Hernia Society) osztályozása szerint a W3-as csoportba soroljuk ezeket. Az óriás hegsérvek sebészi kezelésében a klasszikus hasfali rekonstrukció feszüléssel történik, ez pedig növeli a recidívák arányát. A nagy feszülés következtében jelentôs hasüreginyomás-emelkedés keletkezik, amely kompartmentszindróma kialakulásához és légzési elégtelenség megjelenéséhez vezethet $[1,4]$. A feszüléses has- falzárást elkerülhetjük, ha mû́tét előtt kivizsgáljuk a beteget, a képalkotó eljárásokat alkalmazva meghatározzuk a hegsérv méretét és térfogatát. Ezen esetekben megfelelő megoldásnak bizonyul a számítógépes tomográfia (CT) használata [5]. A hatékonyság ellenőrzése a CT adatai és a mútét alatti és utáni hasưri nyomás értékeivel történik [6]. A hasúri nyomás maghatározásának arany standardjaként a húgyhólyagon keresztüli, Hgmm-ben meghatározott mérést tartják [7]. A mütét utáni morbiditás és mortalitás meghatározására POSSUM-skálát alkalmazunk, amely a hasi mútétek kapcsán egy nemzetközileg elfogadott értékelés $[8,9]$. Az óriás hegsérvek feszülésmentes rekonstrukciója klinikánkon a leggyakrabban a sérvzsákból készített peritoneumlebenyekkel és az izom alá helyezett Prolene hálóval történik.

Célkitûzésünk volt az óriás hegsérvek rekonstrukciójánál alkalmazott mútéti technika hatékonyságának elemzése a hasúrinyomás-méréssel, valamint a preoperatív CT-vizsgálat jelentőségének alátámasztása.

\section{Módszer}

Prospektív multidiszciplináris kutatást végzünk a klinikánkon - a kutatás kezdeti eredményeit dolgoztuk fel, amelyeket három eset bemutatásának kapcsán ismertetünk. A kutatásban részt vevő betegek óriás hegsérvvel rendelkező, 18 évnél idősebb páciensek, akiknél műtét elött CT képalkotó vizsgálat készül. Az alkalmazott mútéti technikát minden esetben ugyanazon sebészi csapat végezte. A hasfal feszülésmentes rekonstrukcióját izom alá helyezett Prolene hálóval és sérvzsákból készített két peritoneumlebeny (peritoneal flap) felhasználásával végezzük. A betegek antibiotikumprofilaxisban részesül- 
nek, amely célra egy dózis, második generációs cefalosporinokat alkalmazunk, a thrombembolicus profilaxisra pedig alacsony molekulasúlyú heparint használunk. Mütét közben és mütét után hasüreginyomás-meghatározás történik, s posztoperatívan követjük a vérlaktátszintet, az oxigénszaturációt és a vesefunkciót. A betegek követése telefonon keresztül történik 2, 4, 6 hónappal a mütétet követően, ami a mütét utáni eredmények vagy a szövődmények megjelenésének megismerését célozza. A hasűrinyomás-méréseket AbViser IAP Monitor segítségével végezzük. A nyomásmérések értékeit, a CT-vizsgálat adatait, valamint a betegek összes többi adatát 2016-os Microsoft Office Excel-táblázatban (Microsoft Corporation, Redmond, WA, Amerikai Egyesült Államok) rögzítjük, valamint ezen belül kerülnek feldolgozásra.

\section{Hasürinyomás-mérés}

A hasüregben levő nyomás mérését indirekt eljárással végezzük. A húgyhólyagba Foley-katétert vezetünk, amelyhez kétosztatú csapot csatolunk, az utóbbit pedig fecskendővel, steril fiziológiás sóoldatos palackkal, nyomásmérővel és vizeletgyújjő zsákkal kötjük össze. A nullpont megfelelője a szeméremcsont magasságának szintjén van meghatározva, a medioaxillaris vonalban. Miután kipréseljük a levegőt a csőrendszerből, a nyomásmérő készülék viszonyítási értékét nullás értékre állítjuk. A fecskendővel $20 \mathrm{ml}$ sóoldatot szívunk ki a palackból, majd átpumpáljuk a kétosztatú csapon, a húgyhólyagba juttatva az oldatot. A csapot egy érzékelőkészülékhez rögzítjük.

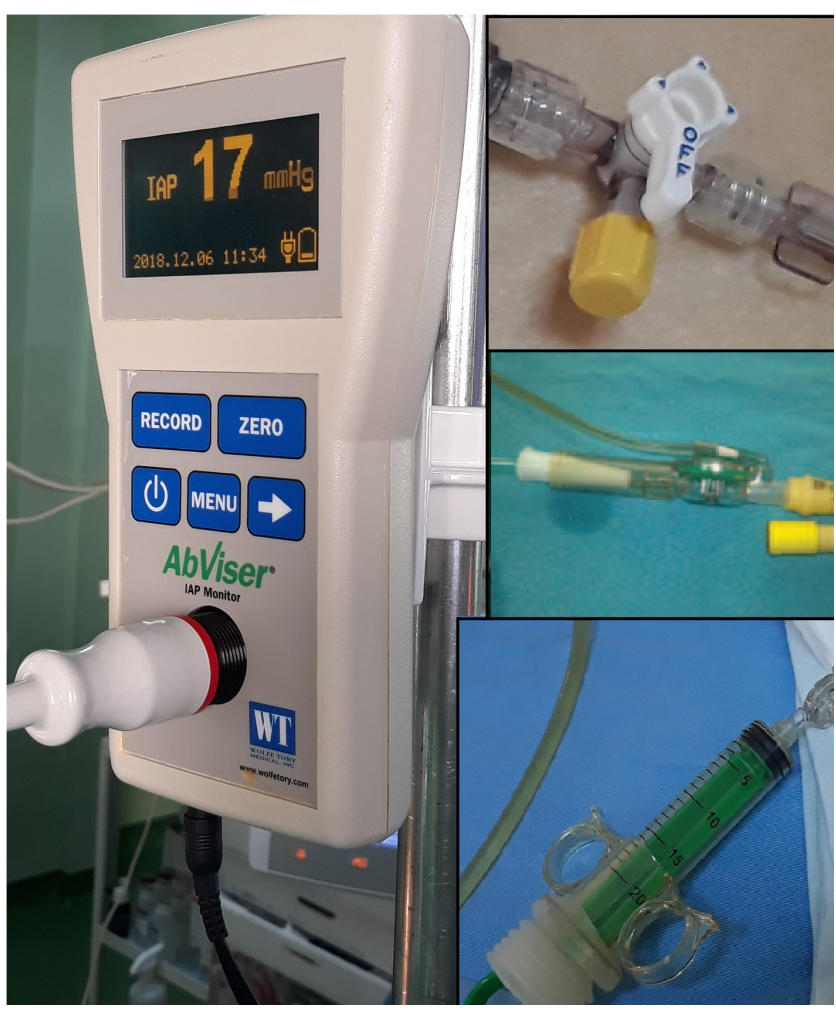

1. ábra

| Hasűrinyomás-mérés az AbViser IAP Monitor alkalmazásával
Az érzékelőkészülékben levő ballon megakadályozza a vizelet elfolyását és érzékeli ennek a nyomását. Ezen érzékelőkészüléktől jut el az információ a kijelző képernyőhöz, amelyről leolvasható a nyomás értéke (1. ábra).

A $20 \mathrm{ml}$ sóoldat 60 másodperc után kezd leszivárogni a vizeletgyưijtő zsákba.

\section{Számítógépes tomográfia}

A CT-vizsgálat a mütétet megelőző napon történt, valamint minden esetben ugyanazon radiológuscsapat végezte a vizsgálatokat és valósította meg azok leírását, csökkentve így a képalkotási kiértékelés változatosságát. A CT képalkotó vizsgálat segítségével meghatározzuk a hegsérvek térfogatának és a hasfali defektusok átmérőjének pontos méretét. A zsigerek hasüregi helyének elvesztési mértékének kiszámításához meghatározzuk a hegsérv térfogata (HSV) és a visszamaradt hasüreg térfogata (ACV) közti arányt, valamint a kapott eredményt megszorozzuk az ellipszoid térfogatoknál alkalmazott becslési tényezővel, amelynek meghatározott értéke 0,52. Egy külön számítási módszer a HSV és a teljes hasüregtérfogat (TPV) (a sérvzsák térfogata és a hasi térfogat összege) közti arány meghatározásán alapul.

\section{Mütéti technika}

A hasfal rekonstrukciója két peritoneumlebennyel történik, amelyeket a sérvzsák középvonalban történő hoszszanti átmetszése során nyerünk. Az egyenes hasizom tokját mindkét oldalon megnyitjuk a lebenyképzés során, illetve az egyik lebeny (hátsó lebeny) az azonos oldali rectushüvely hátsó falán marad. Az első peritonealis lebeny a másik oldali rectushüvely elülső falán marad (2. ábra).

A rekonstrukció során a hátsó lebenyt a túloldali rectushüvely hátsó falához varrjuk, és az így kialakított „falra" helyezzük a Prolene hálót, amely mindkét oldalon az egyenes hasizom lateralis széléig terjed, és a rectushüvely hátsó falához külön Prolene-öltésekkel rögzítődik. Az első peritonealis lebennyel fedjük a Prolene hálót, vala-

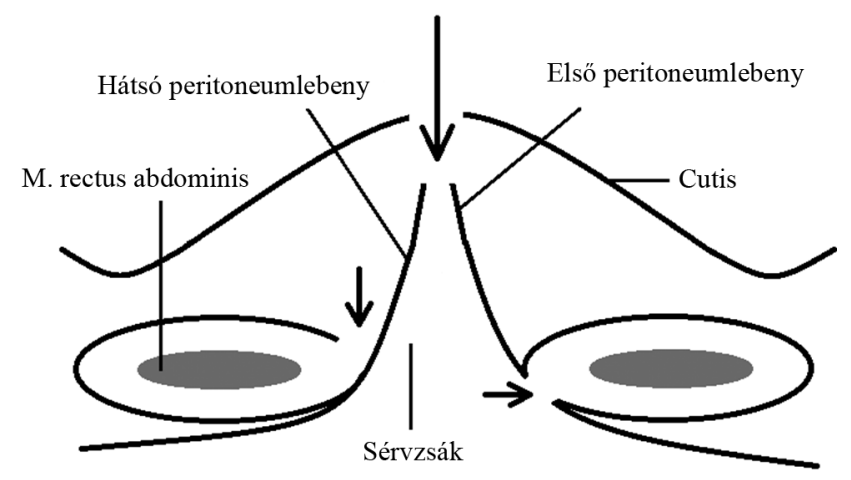

2. ábra A sérvzsákból készített első és hátsó peritoneumlebeny (a nyíl $[\rightarrow]$ a metszések helyét jelzi) 
mint a lebenyt a túloldali rectushüvely elülső falához varrjuk. Ezen mútéti technika kapcsán a zsigereket fedjük a hátsó lebennyel, az izom alá Prolene hálót helyezünk, majd ezt a sérvzsák szabad felével takarjuk. A subcutist lassan felszívódó szállal zárjuk, vagy nagy üreg esetén Redon-drénezést alkalmazunk. A bőrt külön öltésekkel zárjuk.

\section{Etikai eljárások}

Minden beteg aláírta a kórház által rendelkezésre bocsátott beleegyező nyilatkozatot a mútéttel, a kutatással, az adatok feldolgozásával és közlésével, illetve fényképezésükkel kapcsolatosan. A Marosvásárhelyi Orvosi, Gyógyszerészeti, Tudomány- és Technológiai Egyetem etikai bizottsága jóváhagyta ezen kutatás végrehajtását.

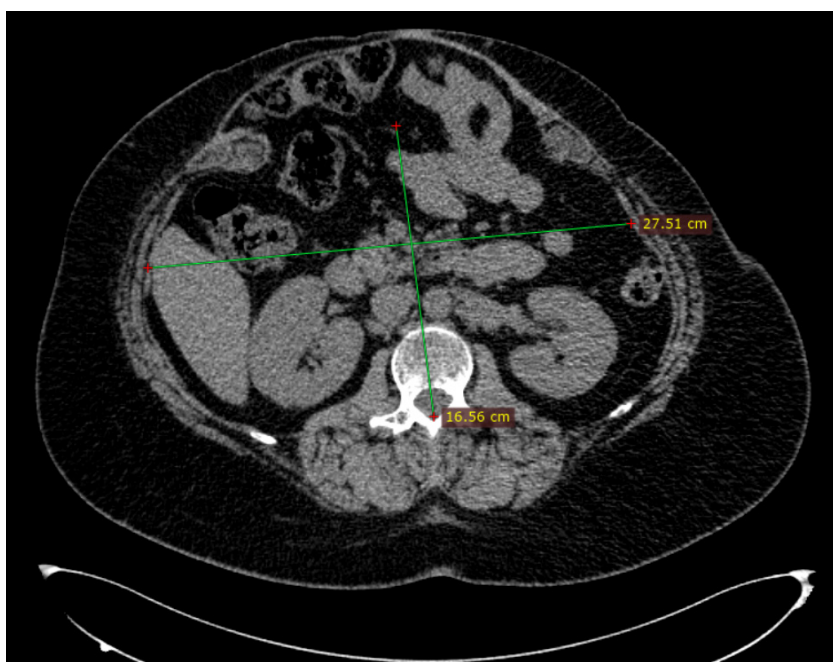

3. ábra

A hasüreg térfogata AP és LL méreteinek meghatározása számítógépes tomográfia segítségével

$\mathrm{AP}=$ anteroposterior $\mathrm{LL}=$ laterolateralis

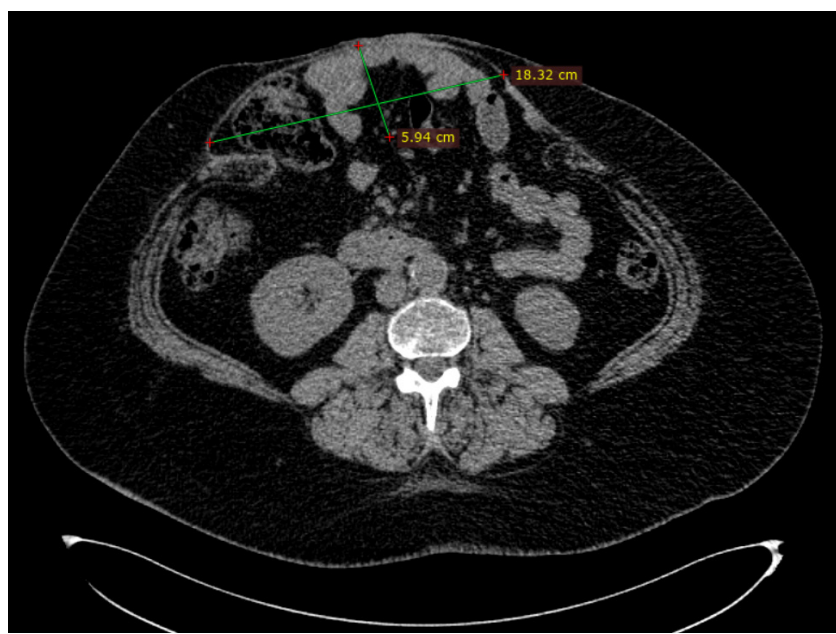

4. ábra

A hegsérv térfogata AP és LL méreteinek meghatározása számítógépes tomográfia segítségével

$\mathrm{AP}=$ anteroposterior $\mathrm{LL}=$ laterolateralis

\section{Eredmények}

\section{Elsó" eset}

A 48 éves nóbeteg recidív óriás hegsérvvel jelentkezett. Egy évvel korábban részesült hasfali rekonstrukcióban. Társbetegségei: cukorbetegség, krónikus ischaemiás cardiopathia és magas vérnyomás. Napi egy csomag cigarettát fogyasztott, testtömegindexe (BMI) 43,6 volt. A mütét elötti CT-vizsgálat enterocolicus tartalommal rendelkező óriás hegsérvet ír le, melynek méretei: $59 / 183 / 282 \mathrm{~mm}$ (AP/LL/CC); a hasfali defektus legnagyobb átméróje $155 \mathrm{~mm}$. A HSV: $1583,27 \mathrm{~cm}^{3}$. A hasüreg méretei: 166/275/390 mm (AP/LL/CC), valamint az ACV: 9257,82 $\mathrm{cm}^{3}$ (3., 4., 5. és 6. ábra).

A TPV értéke: 10841,09 $\mathrm{cm}^{3}$. A HSV/ACV értéke 0,1710, valamint a HSV/TPV aránya 0,1460 (14,6\%). Műtét alatt a hasüregi nyomás átlagmértéke 16 Hgmm volt. A mütét utáni intraabdominalis nyomásmérés alkalmával 20 Hgmm-es értéket kaptunk. Ezen érték a bélmúködés megindulásáig $18 \mathrm{Hgmm-re} \mathrm{csökkent.} \mathrm{A} \mathrm{mú-}$ tét utáni 1. napon az oxigénszaturációja 96\%, a napi vizeletmennyiség $1700 \mathrm{ml}$ volt. A beteget a 7. posztoperatív napon, jó általános állapotban hazabocsátottuk. A felépülésével kapcsolatban kedvező fejlődés volt észlelhető. A POSSUM-érték előre jelzett morbiditása 79,6\%, az előre jelzett mortalitása $25,7 \%$ volt. Az eset jellegze-

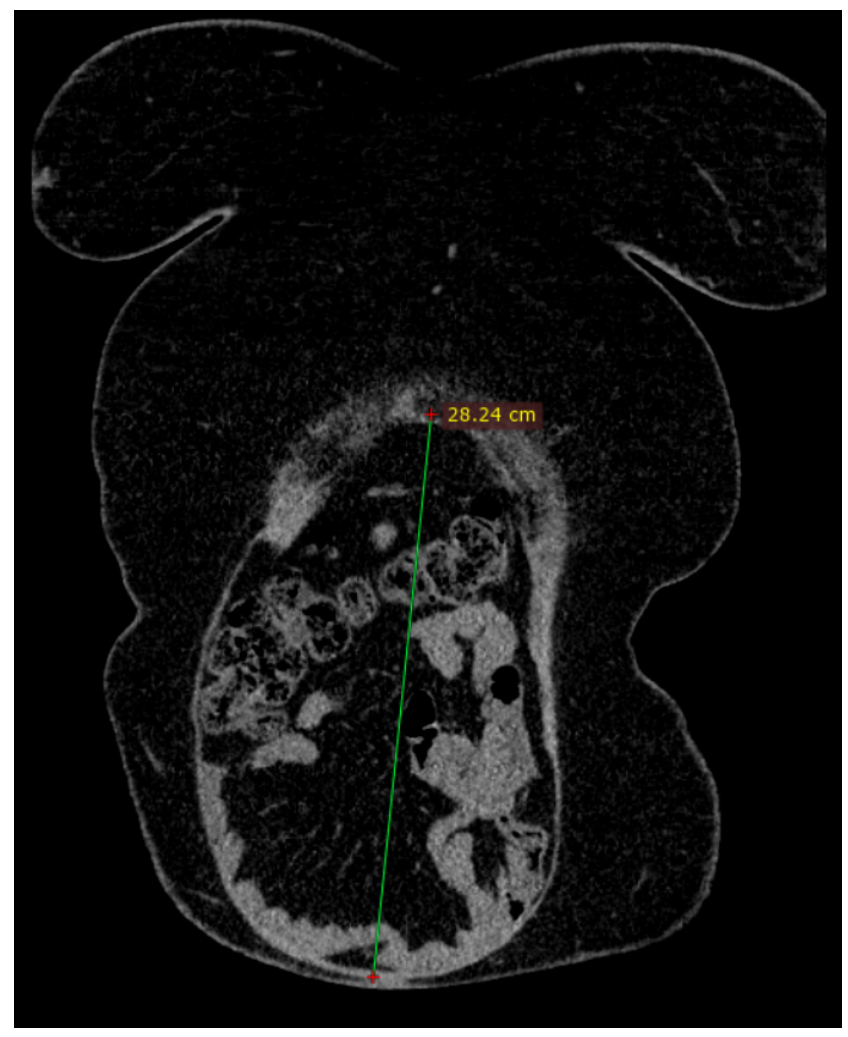

5. ábra A hegsérv CC méretének meghatározása számítógépes tomográfia segítségével

$\mathrm{CC}=$ craniocaudalis 


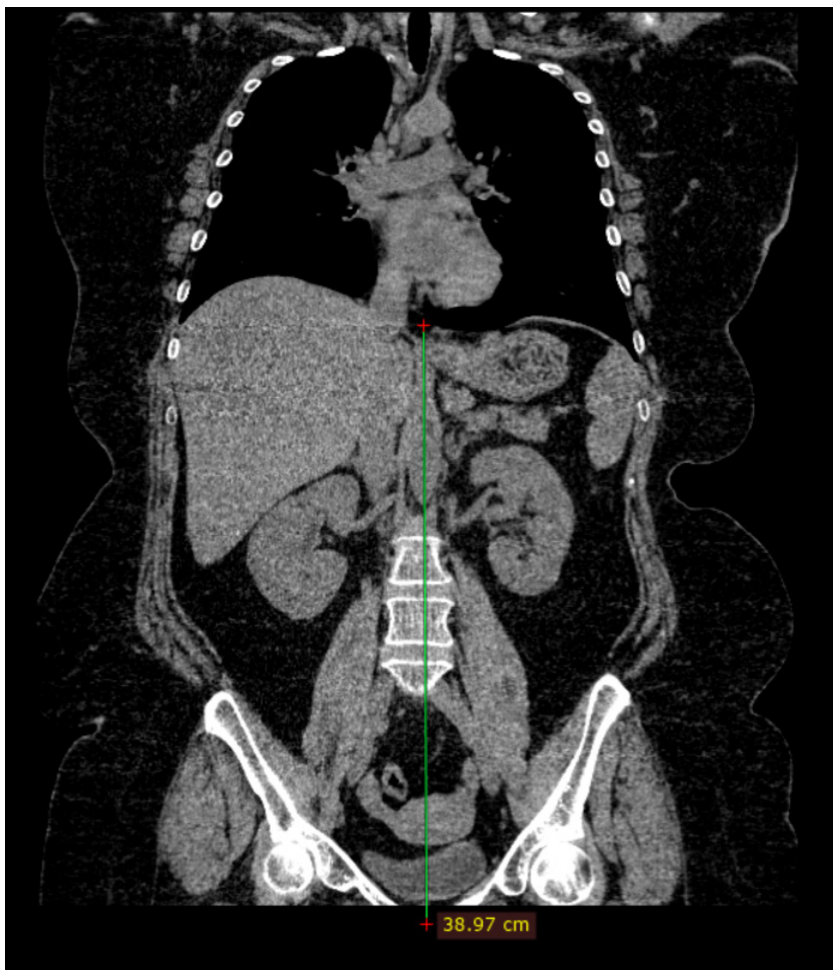

6. ábra

A hasüreg CC méretének meghatározása számítógépes tomográfia segítségével

$\mathrm{CC}=$ craniocaudalis

tességét a társbetegségek, a súlyos elhízás és a POSSUM előre jelzett morbiditásának és mortalitásának magas értéke jelentette.

\section{Második eset}

Az 51 éves férfi beteg multilocularis óriás hegsérvekkel jelentkezett. A páciens napi 20 cigarettát fogyasztott, BMI-értéke 26,85 volt. A CT-leírás két óriás hegsérvet tesz láthatóvá, amelyek méretei 27/103/56 mm, illetve 32/137/94 mm (AP/LL/CC), valamint a két hasfali defektus maximális átméróje $123 \mathrm{~mm}$ és $105 \mathrm{~mm}$, térfogatuk együttes értéke pedig $295,27 \mathrm{~cm}^{3}\left(80,98 \mathrm{~cm}^{3}+\right.$ $\left.214,29 \mathrm{~cm}^{3}\right)$. Az egyik hegsérv tartalmát zsírtartalom és a haránt vastagbél egy része képezi, míg a másik hegsérvben zsírtartalom és ilealis bélkacsok találhatók. A hasüreg méretei: 166/290/370 mm (AP/LL/CC) és az ACV értéke 9262,13 cm³ , továbbá a TPV =9557,4. Az aránypárok értékei a következők voltak: HSV/ACV = 0,0318, HSV /TPV = 0,0308 (3,08\%). Mütét alatt a hasüregi nyomás átlagértéke $15 \mathrm{Hgmm}$ volt, majd a mútétet követően ez az érték 17 Hgmm-re emelkedett. A mütét utáni 1. napon az oxigénszaturációja 99\%, a napi vizeletmennyisége $2050 \mathrm{ml}$ volt. A beteg a mütétet követő 5 . napon, jó általános állapotban és kedvező prognózissal hagyta el a kórházat. A POSSUM előre jelzett morbiditásának értéke 12,3\%, mortalitásának értéke pedig 2,2\% volt. Az eset egyediségét a kettős hegsérv jelenléte adja, valamint az, hogy mindkét defektus meghaladta a 10 cm-es átmérōt.

\section{Harmadik eset}

A 67 éves, óriás hegsérvvel rendelkező férfi beteget előzőleg coecumdaganattal mútötték, BMI-értéke 23,65 volt. A CT-leírás egy köldök feletti óriás hegsérvet ismertet, amelynek tartalmát a haránt vastagbél és néhány bélkacs képezi. A hasfali defektus átmérőjének mérete 100 mm. A hegsérv meghatározott méretei: 27/95/103 $\mathrm{mm}(\mathrm{AP} / \mathrm{LL} / \mathrm{CC})$, a térfogata $137,38 \mathrm{~cm}^{3}$. A hasüreg méretei: $172 / 262 / 335 \mathrm{~mm}$ (AP/LL/CC). További térfogatok meghatározása: $\mathrm{ACV}=7850,14 \mathrm{~cm}^{3}, \mathrm{TPV}=$ $7987,53 \mathrm{~cm}^{3}$, valamint az aránypárok értékei: HSV/ $\mathrm{ACV}=0,0175, \mathrm{HSV} / \mathrm{TPV}=0,0171(1,7 \%)$. A mütétet megelőzően az intraabdominalis nyomás átlaga 10 Hgmm volt, majd a hasfal rekonstrukciója után 11 Hgmm-es nyomást mértünk. A mütét után az 1 . napon az oxigénszaturációja 97\%, valamint a napi vizeletmenynyiség $1500 \mathrm{ml}$ volt. A beteg a mütétet követően 4 nap után hagyta el a kórházat, megfelelő általános állapotban, illetve pozitív fejlődést mutatva. A POSSUM előre jelzett morbiditásának értéke: 42,3\%. A POSSUM előre jelzett mortalitásának értéke: $8,3 \%$.

\section{Megbeszélés}

Óriás hegsérvek gyakran túlsúlyos betegeknél jelentkeznek, de előfordulhatnak normális testsúlyú betegeknél is. A műtét utáni hegsérvek kialakulását tekintve a musculoaponeuroticus réteg szerkezeti épségének elvesztése tehető felelőssé [2]. Az egyetlen kuratív eljárás a nyitott vagy laparoszkópos hasfali rekonstrukció, amelyben a szintetikus hálók megjelenése jelentős előrelépést jelentett. Az óriás hegsérveknél javallt kompozit hálók magas áruk miatt klinikánkon sokszor nem alkalmazhatók [10]. Sikeresen használhatók a makropórusos Prolene hálók, amelyek olcsók és könnyen hozzáférhetók, viszont ezek nem érintkezhetnek a zsigerekkel, erodálás miatt. A Prolene hálók retromuscularis elhelyezésben kitűnő posztoperatív eredményeket biztosítottak. A háló kapcsolata a bő vérellátású izomszövettel elősegíti a korai fibrosis kialakulását, növelvén a hasfal ellenálló képességét $[2,10]$. A sikeres hasfali rekonstrukciók száma fordítottan arányos a hegsérv méretbeli növekedésével [2]. Miután a zsigerek egy része hosszas időn át a sérvzsákban helyezkedett el, a csökkent térfogatú hasüregbe rendkívüli nehézséget jelent ezen zsigerek visszahelyezése, valamint a hasfal feszülésmentes zárása. Olyan mütéti technikára van szükség, amely a háló és a sérvzsák együttes alkalmazását feltételezi. Ez a módszer több elnevezés alatt megtalálható a szakirodalomban, mint Malmö technique, peritoneal flap technique, sublay sandwich technique, illetve peritoneal sandwich technique [11]. Ezen mútéti technika kapcsán a zsigereket fedjük a két egyenlő részre 
osztott sérvzsák egyik felével, majd ezt követően az izom alatti rétegbe helyezünk egy Prolene hálót, illetve ezt a sérvzsák szabad felével takarjuk. Így megelőzzük a háló kapcsolatba lépését a zsigerekkel, valamint a bőr alatti kötőszövettel, elkerülvén a szövődmények kialakulását (haematoma, seroma, bélsipoly) [2, 10]. A sérvzsák felhasználásával a hasfal rekonstrukciója feszülésmentesen valósul meg. A háló mérete minden irányban $5 \mathrm{~cm}$-rel meghaladja a hasfali defektus méretét, ellenkező esetben a kötőszövetes beszűrődés kiváltotta hálózsugorodás recidívához vezet [12]. Ezáltal biztonságos és olcsó technikát hozunk létre. A technika előnyére válik, hogy a hasűri nyomás a háló teljes felületére hat [2]. Egy felmérés alapján bebizonyosodott, hogy a hasfali rekonstrukcióban részesült betegek életminősége jelentősen javult [13]. Egy összefoglaló tanulmány szerint, amely a peritoneal flap műtéti technikának a hatékonyságát vizsgálta a mütött betegek 1-7 évig terjedő utánkövetésével, kijelentette, hogy lényegesen alacsony, 0-13\% közötti kiújulási arányra lehet számítani $[2,11]$. A saját klinikánkon végzett kutatás eredménye szerint hasonló technika (izom alá helyezett Prolene háló és sérvzsák) alkalmazásával a hegsérvek recidívája 5\%-ra tehető, valamint a kiújulással jelentkező betegek mindegyike obesitasban szenvedett [2]. A posztoperatív időszakban előfordulhat a kilégzési tüdőfunkció és a hasfali funkció károsodása, viszont egy év elteltével ezek rendeződnek [13]. Feszülés alatt történő hasfalzáráskor fájdalom, bélmúködési problémák, légzési elégtelenség, valamint keringési elégtelenség jelentkezik [6]. Az intraabdominalis nyomás a hasüregben levő zsigerek közötti nyomás értékét tükrözi [1]. A hasüreginyomás-mérésnek nincsenek káros kihatásai a szervezetre, ezért egymás után többször is elvégezhető. A mútét utáni periódusban addig javallott követni a nyomásértékeket, amíg a betegeknek megindul a bélmúködésük. Ezen nyomás értéke normális keretek között nem haladja meg a $12 \mathrm{Hgmm}-\mathrm{t}$, amelyet három különböző mérés alkalmával határozunk meg 4-6 órás időközönként [1]. Hasüri hipertenzióról akkor beszélünk, ha a nyomásérték 12-20 Hgmm közötti intervallumban található $[1,14]$. Ezt akkor tudjuk biztosan meghatározni, ha a három különböző alkalommal, 4-6 órás időközönként mért hasűri nyomás mindhárom értéke ezen intervallumban található [1]. Ha a hasfal nagy feszülés alatt kerül zárásra, akkor lényegesen nóhet az intraabdominalis nyomás, amely kompartmentszindróma kialakulásához vezet. Ez csökkenti a vérkeringést és a szövetek funkcióját. Abban az esetben állíthatjuk fel a kompartmentszindróma kórisméjét, ha a hasüri nyomás meghaladja a $20 \mathrm{Hgmm}-\mathrm{t}$, és egy vagy több szervi elégtelenség van jelen $[1,4]$. Kezelés nélkül ezen eseteknek a 90\%-a halálozáshoz vezet, valamint kezelést követóen a mortalitás aránya $25 \%$ és $75 \%$ között található [4]. A fokozott nyomásértéket dekompressziós mútéti technikákkal csökkenthetjük [4], valamint ritkább esetekben zsigeri eltávolítás is szükséges lehet (vastagbél, cseplesz) [2]. Ahhoz, hogy elkerülhessünk egy újabb beavatko- zást, szükség van preoperatív képalkotó eljárásokat végezni $[5,15]$. A hegsérvek esetében az ultrahang- és a CT-vizsgálatokat alkalmazzák, amelyek jelentősen kiegészítik a kórismét [16]. Ismervén a CT által leírt térfogatokat, a hasfali defektus átmérőjével kapcsolatos mérési adatokat, a hegsérv morfológiáját, tartalmát, a hasizmok minőségét és a téraránytalanság mértékét, a sebész időben eldöntheti, hogy melyik a legmegfelelőbb alkalmazandó mútéti technika [15]. Az óriás hegsérvek esetében a zsigerek egy része a sérvzsákban helyezkedik el, és így a hasüreg térfogata csökken (loss of domain) [17]. A HSV és a residualis ACV közötti arány meghatározza a téraránytalanság mértékét $[5,15]$. Ezen eljárás megvalósítható, ha külön-külön megmérjük a sérvzsák és a hasüreg mélységét, valamint a legnagyobb szélességi és magassági átmérőjüket. A mérési értékeket milliméterben határozzuk meg. Ezt követően kiszámítjuk a két térfogat közti arány értékét, majd a kapott eredményt beszorozzuk az ellipszoid térfogatoknál alkalmazott becslési tényezővel, amelynek meghatározott értéke 0,52. A két térfogat közötti arány küszöbértéke 0,25. A két térfogat közötti arány mindhárom esetünknél 0,25 alatt volt. Egy másik számítási módszer a HSV és a TPV közti arány meghatározásán alapul. Ezen arány küszöbértéke 20\%-ra tehető. Irodalmi adatok szerint ha a HSV és a TPV közötti arány $20 \%$ alatt van, a zsigerek visszahelyezhetők a hasüregbe, és feszülésmentes hasfali rekonstrukció végezhető múanyag hálók alkalmazásával [18]. Így elkerülhető az intraabdominalis nyomás fokozott növekedése, illetve a kompartmentszindróma kialakulása. Az arány $20 \%$ feletti értékének esetében a has térfogatát növelő módszerek alkalmazása szükséges, mint mütét előtti pneumoperitoneum és botulinustoxin vagy mútét alatt különböző szervek reszekciója (cseplesz, vékonybél, vastagbél) [2]. Ezek a módszerek szövődményekkel járnak, ezért újabban alkalmazásukra ritkán kerül sor. Feszülésmentes hasfali rekonstrukció 20\% feletti arány esetében kompozit hálók alkalmazásával valósítható meg. Ez egy hasfal-helyettesítő (szubsztitúciós) módszer, amely a háló zsigerekre való helyezését feltételezi, amely így a hasfali defektus széleihez rögzítődik (in-lay pozíció) [19]. Az arány mindhárom esetünknél 20\% alatt volt. A küszöbértékek meghaladásával jelentkezhetnek a cardiorespiratoricus elégtelenség tünetei a hasfal zárását követően. A posztoperatív képalkotási eljárások könnyen kimutatják a mütét utáni esetleges szövődményeket [15]. Az elülső hasfalnak a CT-vel könnyen meghatározható fokozott vastagsága egyenesen arányos a szövődménymentes mútétek számával [20]. A mütét utáni eredményeket befolyásolja az obesitas mértéke, ezért fontos a BMI pontos meghatározása. A túlsúlyos betegek esetében gyakrabban jelentkeznek intra- és posztoperatív szövődmények. A korai posztoperatív megfigyelést illetően fontos, hogy a betegeknek folyamatosan mérjük az artériás vérben levő laktátszintjét, oxigénszaturációját, vesefunkcióját és a hasűri nyomását. Így időben fel lehet figyelni egy esetleges kompartmentszindróma kialakulá- 
sának lehetőségére. A hasi patológiákat illetően a colorectalis daganatok rendelkeznek a legnagyobb előfordulási aránnyal. Egy svéd kutatás szerint, amely 28913 colorectalis daganat klasszikus eltávolítását követően tanulmányozta a hegsérvek megjelenését, 5,3\%-os kialakulási arányt írt le [21]. Ezen kutatás szerint a colorectalis daganatok nyílt mütéti eltávolítását követően megjelenő hegsérvek fó rizikótényezői a férfinem, a 70 év alatti életkor, a $\mathrm{BMI}>30$, a 180 percet meghaladó mútéti idő és a mûtét utáni szövődmények a zárási seb szintjén [21]. Mindezek szerint a beteg súlya, a hegsérv mérete és a mütéti technikák jelentősen befolyásolják a mütét kimenetelét és a mütét utáni hasüregben uralkodó nyomás értékét.

\section{Következtetés}

A hasfal rekonstrukciója izom alá helyezett Prolene hálóval és sérvzsákból készített két peritoneumlebennyel egyszerű, olcsó és feszülésmentes technikát biztosít. Biztonsággal alkalmazható a fokozott kockázattal rendelkező betegek esetében is. A preoperatív CT-vizsgálat kötelező jellegü, és jelentős adatokkal szolgál a mütéti technika megválasztásához. A technika rövid távú hatékonyságának elemzésére és a mütét utáni szövődmények korai felismerésére a húgyhólyagon keresztül történő hasűrinyomás-mérés a választandó módszer.

Anyagi támogatás: A jelen munkát a Magyarország Collegium Talentum 2019 programja támogatta.

Szerzői munkamegosztás: F. Zs. Z.: Sebészi kezelés, az esetek elemzése, a kézirat megírása. Ifj. B. T.: Sebészi kezelés, a hasûrinyomás-mérések végrehajtása, kapcsolattartó személy. S. P.: A radiológiai vizsgálatok és mérések elvégzése, az ábrák szerkesztése. Sz. M.: Az esztétikai hasfalzárás megvalósítása. D. E.: A helyesírási hibák javítása, a kézirat formai szerkesztése. F. R. L.: A betegek utánkövetése, telefonos kapcsolattartás. J. J.: Útmutatás a kézirat szerkesztésében. B. T.: Sebészi kezelés, az irodalom elemzése. A cikk végleges változatát valamennyi szerző elolvasta és jóváhagyta.

Érdekeltségek: A szerzőknek nincsenek érdekeltségeik.

\section{Irodalom}

[1] Muresan M, Muresan S, Bara T, et al. The intraabdominal pressure. A real indicator of the tension free principle during anterior wall repair procedure after incisional hernias. Ann Ital Chir. 2015; 86: 421-426

[2] Bara T Jr, Gurzu S, Borz C, et al. Retromuscular mesh and hernial sac technique in the reconstruction of 139 cases of large median incisional hernias: one institution's experience. Hernia 2019 Feb 26. doi: 10.1007/s10029-019-01915-x. [Epub ahead of print]
[3] Coțofană M, Muşat F, Păduraru DN, et al. Predictive factors for intraabdominal hypertension after incisional hernia repair. Chirurgia (Bucur) 2019; 114: 12-17.

[4] Muresan M, Muresan S, Brinzaniuc K, et al. How much does decompressive laparotomy reduce the mortality rate in primary abdominal compartment syndrome? A single-center prospective study on 66 patients. Medicine (Baltimore) 2017; 96: e6006.

[5] Ion D, Stoian RV, Păduraru DN, et al. Difficult incisional hernia nosological settings and approach strategies. J Surg Sci. 2018; 5 : 237-241.

[6] Angelici AM, Perotti B, Dezzi C, et al. Measurement of intraabdominal pressure in large incisional hernia repair to prevent abdominal compartmental syndrome. G Chir. 2016; 37: 31-36.

[7] Milanesi R, Caregnato RC. Intra-abdominal pressure: an integrative review. Einstein (Sao Paulo) 2016; 14: 423-430.

[8] Lima MJ, Cristelo DF, Mourão JB. Physiological and operative severity score for the enumeration of mortality and morbidity, frailty, and perioperative quality of life in the elderly. Saudi J Anaesth. 2019; 13: 3-8.

[9] Mzoughi Z, Bayar R, Djebbi A, et al. The POSSUM: a good scoring system for predicting mortality in elderly patients undergoing emergency surgery? Pan Afr Med J. 2016; 24: 166.

[10] Bara T, Bancu S, György-Fazakas I, et al. Reconstruction of incisional median hernia with retromuscular positioned mesh and hernial sac. [Posztoperatív medián sérvek rekonstrukciója retromuscularis helyzetű sérvzsákkal borított hálóval.] Magy Seb. 2007; 60: 136-139. [Hungarian]

[11] Köckerling F, Scheuerlein H, Schug-Pass C. Treatment of large incisional hernias in sandwich technique - a review of the literature. Front Surg. 2018; 5: 37.

[12] Kokotovic D, Bisgaard T, Helgstrand F. Long-term recurrence and complications associated with elective incisional hernia repair. JAMA 2016; 316: 1575-1582.

[13] Jensen KK. Recovery after abdominal wall reconstruction. Dan Med J. 2017; 64: B5349.

[14] Cheatham ML. Intra-abdominal pressure: why are you not measuring it? Crit Care Med. 2014; 42: 467-469.

[15] Halligan S, Parker SG, Plumb AA, et al. Imaging complex ventral hernias, their surgical repair, and their complications. Eur Radiol. $2018 ; 28: 3560-3569$

[16] Kroese LF, Sneiders D, Kleinrensink GJ, et al. Comparing different modalities for the diagnosis of incisional hernia: a systematic review. Hernia 2018; 22: 229-242.

[17] Azar FK, Crawford TC, Poruk KE, et al. Ventral hernia repair in patients with abdominal loss of domain: an observational study of one institution's experience. Hernia 2017; 21: 245-252.

[18] Torregrosa-Gallud A, Sancho Muriel J, Bueno-Lledó J, et al. Modified components separation technique: experience treating large, complex ventral hernias at a University Hospital. Hernia 2017; 21: 601-608.

[19] Holihan JL, Nguyen DH, Nguyen MT, et al. Mesh location in open ventral hernia repair: a systematic review and network meta-analysis. World J Surg. 2016; 40: 89-99.

[20] Blair LJ, Ross SW, Huntington CR, et al. Computed tomographic measurements predict component separation in ventral hernia repair. J Surg Res. 2015; 199: 420-427.

[21] Söderbäck H, Gunnarsson U, Hellman P, et al. Incisional hernia after surgery for colorectal cancer: a population-based register study. Int J Colorectal Dis. 2018; 33: 1411-1417.

(Ifj. Bara Tivadar dr., Gheorghe Marinescu u. 50., Marosvásárbely, 540136, Románia e-mail: barativadar@yahoo.com) 